\title{
Studi Interaksi Obat Antihiperlipidemia Pada Pasien Rawat Jalan RSUD dr. M.M. Dunda Limboto
}

\section{Antihyperlipidemic Drugs Interactions To The Outpatients At dr. M.M Dunda Limboto Regional Public Hospital}

\author{
Rahmawaty Hasan \\ Program Studi Farmasi, Fakultas Ilmu Kesehatan, Universitas Ibrahimy \\ Email: rahmahasan1234@gmail.com
}

\begin{abstract}
ABSTRAK
Hiperlipidemia merupakan suatu keadaan ketidaknormalan metabolisme lipid yang ditandai dengan adanya peningkatan kadar lipid dalam darah. Hiperlipidemia sering diikuti dengan penyakit lain. Sehingga pengobatan hiperlipidemia sering dikombinasikan bersama obat lain dan berpotensi meningkatkan terjadinya interaksi obat. Penelitian ini bertujuan untuk mengidentifikasi tingkat keparahan interaksi obat antihiperlipidemia pada pasien rawat jalan RSUD Dr. M.M Dunda Limboto periode Januari sampai Maret 2018. Penelitian ini termasuk penelitian observasi (survei), jenis penelitian survei analitik dan data diambil secara retrospektif. Jenis analisis data adalah analisis univariat dan data dikelola secara teoritik menggunakan Stockley Drug Interaction dan review aplikasi drugs.com. Dari 170 lembar resep yang memenuhi kriteria inklusi, diperoleh 67,65 \% berpotensi mengalami interaksi obat dan 32,35\% tidak mengalami interaksi obat. Antihiperlipidemia yang sering diresepkan dan paling besar menimbulkan interaksi obat adalah simvastatin (64,12\%). Dari 170 lembar resep, ditemukan 209 kasus tingkat keparahan interaksi obat, dengan tingkat keparahan minor sebesar $27,27 \%$, tingkat keparahan moderat sebesar 47,85\% dan tingkat keparahan mayor sebesar 24,88 \% .
\end{abstract}

Kata kunci: interaksi obat, antihiperlipidemia, resep

\begin{abstract}
Hyperlipidemia is an abnormal lipid condition of metabolism which is characterized by increasing the level of blood lipid. Hyperlipidemia is often followed by other diseases. Therefore, the treatment of hyperlipidemia is often combined with other drugs and potentially increases the occurrence of drugs interactions. This study aimed to identify the severity of antihyperlipidemic drugs interactions to the outpatients at Dr. M.M Dunda Limboto Regional Public Hospital on January to March 2018.This research was included in the observation (survey) research, the type of research was the analytic survey and the data was obtained retrospectively. The type of data analysis was univariate analysis and the data was managed theoretically using the guidelines of Stockley Drug Interaction and drugs.com application review. Of the 170 prescription sheets that met the inclusion criteria, $67.65 \%$ were potentially triggered the drugs interactions and $32.35 \%$ had no drugs interactions. One of Antihyperlipidemic drug was often prescribed and mostly generated the interactions was simvastatin (64.12\%). Of the 170 prescriptions, 209 cases of severity of drugs interactions were found, with minor severity of $27.27 \%$, moderate severity of $47.85 \%$ and major severity of $24.88 \%$.
\end{abstract}

Keywords: drugs interactions, antihyperlipidemic, prescription

\section{PENDAHULUAN}

$$
\text { Perkumpulan Endokrinologi }
$$

Indonesia tahun 2015 mengemukakan

bahwa Indonesia sedang menjalani

fenomena perubahan epidemiologi.
Perubahan epidemiologi adalah suatu keadaan kesehatan masyarakat dimana terjadi peningkatan epidemik penyakit tidak menular. Perubahan pola hidup dan ketidaktepatan asupan nutrisi telah 
berdampak terhadap timbulnya berbagai perubahan pada pola penyakit. Berdasarkan laporan WHO tahun 2012, menunjukkan bahwa penyakit jantung koroner dan stroke iskemik adalah penyakit utama penyebab kematian (mortalitas) di dunia. Pada tahun 2012 penyakit jantung koroner dan stroke iskemik berkontribusi terhadap 14,2 juta kematian di dunia.

Sebagai upaya untuk menurunkan angka kematian akibat penyakit jantung koroner dan stroke iskemik, diperlukan kompleksitas pengobatan untuk menurunkan kadar lipid dalam darah. Menurut Grundy (2002), dalam setiap penurunan kadar LDL (Low Density Lipoprotein) dalam darah sebesar $30 \mathrm{mg} / \mathrm{dL}$ akan menekan naiknya risiko relatif terhadap kejadian penyakit jantung koroner yaitu sebesar $30 \%$. Penanganan hiperlipidemia adalah strategi ideal untuk mengurangi beban penyakit kardiovaskular. Akan tetapi dengan meningkatnya kompleksitas pengobatan yang digunakan saat ini seiring dengan berkembangnya polifarmasi maka kemungkinan terjadinya interaksi obat makin besar. Interaksi obat dianggap penting secara klinik jika berakibat meningkatkan toksisitas atau mengurangi efektifitas obat yang berinteraksi (Cipolle, 1998).

Berdasarkan observasi awal yang telah dilakukan di Apotek RSUD Dr. M.M Dunda Limboto ditemukan kejadian klinis interaksi obat. Adapun jenis antihiperlipidemi yang paling sering diresepkan dan menimbulkan interaksi obat adalah simvastatin dan gemfibrozil. Simvastatin dan gemfibrozil sering diresepkan bersama antihipertensi (amlodipin), antidiabetik (metformin) serta omeprazol dan lansoprazol. Interaksi tersebut dapat meningkatkan risiko kejang otot atau miopati dan gagal ginjal akibat pelepasan mioglobulin dari otot yang rusak ke dalam darah.

\section{METODE PENELITIAN}

Penelitian observasional ini adalah jenis penelitian survei analitik. Rancangan penelitian ini adalah rancangan survei cross sectional dengan menggunakan data yang bersifat retrospektif.

Sampel penelitian berupa lembar resep pasien rawat jalan periode Januari sampai Maret 2018 dengan peresepan antihiperlipidemia di Apotek RSUD Dr. M.M Dunda Limboto menggunakan teknik purposive 
sampling. Data yang digunakan adalah jenis data sekunder dengan jenis analisis data berupa analisis univariat. Analisis univariat dalam penelitian ini meliputi analisis dektriptif data karakteristik pasien meliputi umur dan jenis kelamin, karakteristik obat yaitu jumlah jenis obat yang diterima pasien, serta gambaran interaksi obat yang dialami pasien. Selanjutnya data dikelola berdasarkan studi literatur menggunakan buku teks Drug Interactions Stockley $8^{\text {th }}$ Edition dan telaah aplikasi interaksi obat dengan menggunakan drugs.com. Analisis data dilakukan dengan menghitung persentase tingkat kejadian interaksi obat berdasarkan tingkat keparahan, yaitu mulai dari minor, moderat sampai mayor.

\section{HASIL DAN PEMBAHASAN}

Dari penelitian didapatkan 170 peresepan antihiperlipidemia oral pada pasien rawat jalan RSUD Dr. M.M Dunda Limboto periode Januari sampai Maret 2018. Hasil penelitian dapat diuraikan sebagai berikut.

Tabel 1. Distribusi Pasien Berdasarkan Jenis Kelamin

\begin{tabular}{cccc}
\hline \multirow{3}{*}{ No } & $\begin{array}{c}\text { Jenis } \\
\text { Kelamin }\end{array}$ & $\begin{array}{c}\text { Jumlah } \\
\text { Resep }\end{array}$ & $\begin{array}{c}\text { Persentase } \\
(\mathbf{\%})\end{array}$ \\
\hline 1 & Laki-laki & 59 & 34,71 \\
2 & Perempuan & 111 & 65,29 \\
Total & & $\mathbf{1 7 0}$ & $\mathbf{1 0 0}$ \\
\hline
\end{tabular}

Berdasarkan tabel 4.1, diketahui bahwa dari 170 jumlah lembar resep pasien rawat jalan RSUD Dr. M.M Dunda Limboto yang menerima peresepan antihiperlipidemia terdapat 111 pasien $(65,29 \%)$ berjenis kelamin perempuan dan 59 pasien $(34,71 \%)$ berjenis kelamin laki-laki. Menururt Bull, dkk (2007), perempuan lebih tinggi berisiko memiliki kadar kolesterol yang tinggi dari laki-laki. Hal ini disebabkan oleh faktor hormonal. Pada saat wanita memasuki usia 50 tahun atau mengalami menopause, wanita memiliki pelindung alami terhadap penyakit jantung yaitu hormon estrogen. Hormon estrogen berperan dalam menjaga tingkat HDL (High Density Lipoprotein) agar tetap tinggi dan LDL (Low Density Lipoprotein) yang tetap rendah.

Tabel 2. Distribusi Pasien Berdasarkan

\begin{tabular}{lccc}
\multicolumn{5}{c}{ Umur } & & \\
\hline No & $\begin{array}{c}\text { Rentang } \\
\text { Umur }\end{array}$ & $\begin{array}{c}\text { Jumlah } \\
\text { Resep }\end{array}$ & $\begin{array}{c}\text { Persentase } \\
(\%)\end{array}$ \\
\hline 1 & $<20$ & 1 & 0,59 \\
2 & $30-39$ & 4 & 2,35 \\
3 & $40-49$ & 30 & 17,65 \\
4 & $50-59$ & 80 & 47,06 \\
5 & $60-69$ & 32 & 18,82 \\
6 & $\geq 70$ & 23 & 13,53 \\
Total & & $\mathbf{1 7 0}$ & $\mathbf{1 0 0}$ \\
\hline
\end{tabular}

Berdasarkan tabel 2 diketahui bahwa peresepan antihiperlipidemia 
oral paling banyak ditemukan pada rentang umur 50 sampai 59 tahun, yaitu sebesar 80 pasien (47,06\%). Menurut Brunton, dkk (2010), angka kejadian pasien dengan gangguan jantung dengan faktor risiko hiperlipidemia terbesar pada pasien dengan rentang umur 45 sampai 65 tahun. Menurut Woodward, dkk (2007), proses degeneratif dan meningkatnya paparan agen berbahaya kolesterol, serta proses terjadinya aterosklerosis berkontribusi pada tingginya kejadian hiperlipidemia pada umur di atas 50 tahun. Hal ini sesuai dengan kejadian pada peresepan antihiperlipidemia, dimana angka kejadian pasien dengan rentang umur 50 sampai 59 tahun adalah yang paling besar, yaitu 80 pasien (54\%).

Tabel 3. Distribusi Resep Berdasarkan Ada Tidaknya Interaksi Obat

\begin{tabular}{ccccc}
$\begin{array}{c}\text { Jumlah } \\
\text { Obat }\end{array}$ & \multicolumn{2}{c}{ Jumlah Resep } & \multicolumn{2}{c}{ Persentase (\%) } \\
& $\begin{array}{c}\text { Ada } \\
\text { Interaksi }\end{array}$ & $\begin{array}{c}\text { Tidak } \\
\text { Ada }\end{array}$ & $\begin{array}{c}\text { Ada } \\
\text { Interaksi }\end{array}$ & $\begin{array}{c}\text { Tidak } \\
\text { Ada }\end{array}$ \\
\hline $2-4$ & 32 & 25 & 18,82 & 14,71 \\
$\geq 5$ & 83 & 30 & 48,83 & 17,64 \\
Total & $\mathbf{1 1 5}$ & $\mathbf{5 5}$ & $\mathbf{6 7 , 6 5}$ & $\mathbf{3 2 , 3 5}$ \\
\hline
\end{tabular}

Berdasarkan hasil analisis lembar resep pasien rawat jalan yang menerima obat antihiperlipidemia oral, bahwa potensi interaksi obat lebih banyak terjadi pada lembar resep yang tedapat jumlah obat $\geq 5$, yaitu sebanyak
83 lembar resep (48,83\%), sedangkan yang potensi interaksi obat lebih sedikit terjadi pada lembar resep yang terdapat jumlah obat 2 sampai 4, yaitu 32 lembar resep $(18,82 \%)$ dari total sampel 170 lembar resep. Hal ini sesuai dengan penelitian Dewi dkk (2014) yang mengutip Reikvam dkk (2006) bahwa makin banyak jumlah obat yang digunakan maka akan semakin besar pula terjadinya problem terapi obat pada pasien, dimana kejadian interaksi obat adalah salah satu diantaranya. Hal tersebut juga sesuai dengan Johnson (1994), semakin meningkatnya jumlah obat yang digunakan pasien, risiko terjadinya interaksi obat juga semakin tinggi, risiko terjadinya interaksi obat kurang lebih naik $6 \%$ pada pasien yang menerima dua obat, $50 \%$ untuk pasien dengan lima obat hingga $100 \%$ bagi pasien yang menerima lebih dari 10 macam obat.

Tabel 4. Gambaran Interaksi Obat Berdasarkan Penggunaan Antihiperlipidemia

\begin{tabular}{ccccc}
\hline $\begin{array}{c}\text { Golongan } \\
\text { Obat }\end{array}$ & Nama Obat & N & n & \% \\
\hline Statin & Simvastatin & 156 & 109 & 64,12 \\
Fibrat & Gemfibrozil & 9 & 1 & 0,59 \\
Kombinasi & Simvastatin- & 5 & 5 & 2,94 \\
& Gemfibrozil & $\mathbf{1 7 0}$ & $\mathbf{1 1 5}$ & $\mathbf{6 7 , 6 5}$ \\
\hline \multirow{2}{*}{ Total } & jumlah resep $; n=$ jumlah resep
\end{tabular}

yang mengalami interaksi obat 
Berdasarkan tabel di atas, diketahui bahwa kelompok pasien yang menerima peresepan antihiperlipidemia terbesar adalah jenis simvastatin, yaitu sebesar 109 resep $(64,12 \%)$. Selanjutnya jenis antihiperlipidemia yang paling sering diresepkan adalah kombinasi golongan fibrat dan statin, yaitu gemfibrozil dan simvastatin sejumlah 5 resep $(2,94 \%)$.

Menurut Katzung (1984), obat golongan inhibitor HydroxyMethylglutaryl Koenzim A reduktase atau statin bekerja sebagai inhibitor kompetitif enzim HMG KoA reduktase yang reversibel. Karena aktivitasnya yang kuat terhadap enzim, statin efektif sebagai antihiperlipidemia dengan cara berkompetitif menempati reseptor HMG KoA reduktase. HMG KoA reduktase adalah enzim yang bertanggung jawab untuk konversi HMG KoA menjadi asam mevalonat yang merupakan tahap awal dalam jalur biosintesis kolesterol. Penghambatan biosintesis kolesterol hati oleh inhibitor HMG KoA reduktase meningkatkan reseptor LDL dalam mengikat partikel LDL dalam hati dan mengeluarkannya dari sirkulasi. Jadi efek obat ini ialah menurunkan sintesis kolesterol dalam sel hati dengan cara meningkatkan jumlah reseptor LDL.

Menurut Knopp (1999), fibrat adalah agonis dari PPAR- $\alpha$ (Peroxisome Proliferators Activated Receptor alfa), melalui reseptor ini fibrat menurunkan regulasi gen apoCIII serta meningkatkan regulasi gen apoA-I dan apoA-II. Berkurangnya sintesis apoC-III menyebabkan peningkatan katabolisme trigliserida oleh lipoprotein lipase, berkurangnya pembentukan kolesterol VLDL, dan meningkatnya pembersihan kilomikron 
Tabel 5. Data Distribusi Tingkat Keparahan Interaksi Obat Antihiperlipidemia (drugs.com)

\begin{tabular}{clccc}
\hline Tingkat Keparahan & \multicolumn{1}{c}{ Interaksi Obat } & Tingkat Signifikansi & Jumlah Kasus & Persentase (\%) \\
\hline \multirow{5}{*}{ Minor } & Simvastatin - Karbamazepin & 3, Suspected & 8 & 3,83 \\
& Simvastatin - Klopidogrel & 5, Unlikely & 35 & 16,75 \\
& Simvastatin - Metformin & 5, Possible & 14 & 6,70 \\
& Gemfibrozil - Metformin & 2, Suspected & 1 & 0,46 \\
& Simvastatin - Asam Asetilsalisilat & 4, Possible & 20 & 9,57 \\
& Simvastatin - Ciprofloksasin & 2, Suspected & 3 & 1,45 \\
\multirow{5}{*}{ Moderat } & Simvastatin - Hidroklortiazid & 2, Suspected & 1 & 0,46 \\
& Simvastatin - ISDN & 2, Suspected & 31 & 14,83 \\
& Simvastatin - Lansoprazol & 2, Suspected & 16 & 7,67 \\
& Simvastatin - Omeprazol & 2, Suspected & 28 & 13,40 \\
& Gemfibrozil - Simvastatin & 1, Suspected & 5 & 2,41 \\
& Mayor & 1, Suspected & 46 & 22,01 \\
& Simvastatin - Amlodipin & 1, Suspected & 1 & 0,46 \\
& Simvastatin - Telmisartan & & $\mathbf{2 0 9}$ & $\mathbf{1 0 0}$ \\
\hline
\end{tabular}

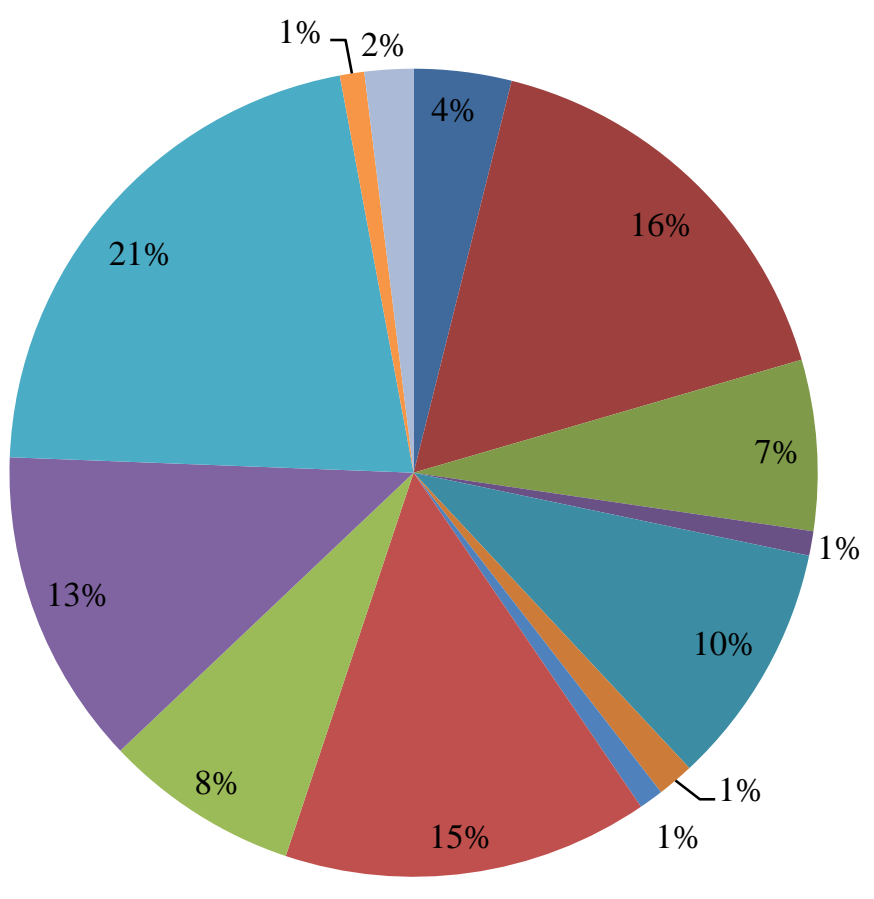

- Simvastatin-Karbamazepin

- Simvastatin-Klopidogrel

- Simvastatin-Metformin

- Gemfibrozil-Metformin

- Simvastatin-ASA

- Simvastatin-Ciprofloksasin

- Simvastatin-HCT

- Simvastatin-ISDN

- Simvastatin-Lansoprazol

- Simvastatin-Omeprazol

- Simvastatin-Amlodipin

- Simvastatin-Telmisartan

- Gemfibrozil-Simvastatin

Dalam penelitian ini dari 115 lembar resep antihiperlipidemia yang mengalami interaksi obat, terdapat 209 kasus diantaranya dengan tingkat keparahan interaksi obat. Tingkat kejadian interaksi obat paling besar ditemukan pada tingkat keparahan sedang (moderat) yaitu sebanyak 100 kasus (47,85 \%). Adapun tingkat keparahan ringan (minor) ditemukan sebanyak 57 kasus $\quad(27,27 \%)$, serta tingkat keparahan berat (mayor) sebanyak 52 kasus $(24,88 \%)$ dari total 209 kasus interaksi obat. 
Dari 57 kasus interaksi obat dengan tingkat keparahan ringan (minor), terdapat 8 peresepan simvastatin dan karbamazepin. Menurut Stockley Drug Interactions, penggunaan simvastatin bersama karbamazepin dapat menurunkan kadar simvastatin dalam darah dari $75 \%$ sampai $68 \%$. Dari 57 kasus interaksi obat dengan tingkat keparahan ringan (minor), terdapat 35 peresepan simvastatin dan klopidogrel, serta 14 peresepan simvastatin dan metformin. Penggunaan simvastatin bersama klopidogrel dan simvastatin bersama metformin tidak secara signifikan mempengaruhi biovabilitas simvastatin dan secara klinis tidak berdampak pada pasien.

Dari 100 kasus interaksi obat dengan tingkat keparahan sedang (moderat), terdapat 28 peresepan simvastatin dan omeprazol, 16 peresepan simvastatin dan lansoprazol, 1 peresepan simvastatin dan hidroklortiazid, 31 peresepan simvastatin dan isosorbid dinitrat, 20 peresepan simvastatin dan asam asetilsalisilat, serta 3 peresepan simvastatin dan ciprofloksasin. Menurut Stockley Drug Interactions, penggunaan simvastatin bersama omeprazol, lansoprazol dan ciprofloksasin dapat meningkatkan kadar simvastatin dalam darah dan juga meningkatkan risiko efek samping rabdomiolisis. Sedangkan penggunaan simvastatin bersama hidroklortiazid, asam asetilsalisilat dan isosorbid dinitrat dapat menyebabkan risiko kerusakan pada sistem saraf.

Dari 52 kasus interaksi obat dengan tingkat keparahan berat (mayor), terdapat 46 peresepan simvastatin dan amlodipin. Menurut Stockley Drug Interactions, penggunaan simvastatin bersama amlodipin dapat meningkatkan kadar simvastatin dalam darah sampai $\pm 50 \%$. Penggunaan simvastatin bersama amlodipin juga sangat meningkatkan risiko rabdomiolisis dan memperburuk efek samping kejang otot atau miopati. Dari 65 kasus interaksi obat dengan tingkat keparahan berat (mayor), terdapat 1 peresepan simvastatin dan telmisartan serta 5 peresepan kombinasi antihiperlipidemia simvastatin dan gemfibrozil. Kombinasi obat tersebut dapat meningkatkan kadar simvastatin dalam darah dan meningkatkan risiko kerusakan pada hati. Kombinasi simvastatin dan gemfibrozil juga dapat 
menyebabkan efek samping kejang dan kaku otot (miopati) serta rabdomiolisis.

Penatalaksanaan interaksi obat dengan tingkat keparahan minor dapat dilakukan dengan menaikkan dosis terapi simvastatin dari $20 \mathrm{mg}$ sampai dengan $80 \mathrm{mg}$ pada kombinasi simvastatin dan karbamazepin. Adapun penanganan interaksi obat dengan tingkat keparahan moderat dengan efek samping berupa meningkatnya kadar simvastatin dalam darah serta risiko miopati dan rabdomiolisis adalah dengan mengatur dosis simvastatin agar tidak melebihi $20 \mathrm{mg}$ per hari atau dengan memilih alternatif terapi statin lainnya seperti Fluvastatin, Pravastatin dan Rosuvastatin. Sedangkan penatalaksanaan interaksi obat dengan tingkat keparahan mayor dilakukan dengan mengatur dosis simvastatin agar tidak melebihi $20 \mathrm{mg}$ per hari dan disertai monitoring kreatinin kinase dan efek neuropati pada penderita miopati dan rabdomiolisis (Liman dan Hartadi, 2001).

\section{SIMPULAN DAN SARAN}

1. Dari 170 lembar resep, terdapat $67,65 \%$ diantaranya terjadi interaksi obat dan 32,35\% tidak terjadi interaksi obat.
2. Tingkat keparahan interaksi obat antihiperlipidemia mulai dari tingkat keparahan minor yaitu sebesar 27,27\%, tingkat keparahan moderat sebesar $47,85 \%$, serta tingkat keparahan mayor sebesar $24,88 \%$.

\section{DAFTAR PUSTAKA}

Abdullah. 2013. Profil RSUD Dr. M.M Dunda Limboto Kabupaten Gorontalo. Gorontalo: RSUD Dr. M.M Dunda.

Ament P.W, Bertolino J.G, Liszewski J.L. $2000 . \quad$ Clinical Pharmacology: Clinically Significant Drug Interactions. New York: Am Fam Physician.

American Therapeutic Research Centre. 2012. Pharmacist's Letter: Clinically Significant Statin Drug Interactions. United States: Prescriber's Letter.

Arsil Y, Helmi A, Darwin D, Raveinal. 2011. Analisa Interaksi Obat Pasien Dislipidemia di Bangsal Rawat Inap dan Rawat Jalan Penyakit Dalam RSUP Dr. M. Djamil. Padang: Universitas Andalas.

Boroujeni H.R, Heidarian E, Mohammadizadeh F, Kopaei, M.R. 2015. Herbs with Anti-lipid Effects and Their Interactions with Statins As a Chemical Antihyperlipidemic Group Drugs. Iran: Shahrekord University of Medical Science. 
Brunton L.L, Chabner A.B, Knollmann C. 2010. Goodman and Gilman's : The Pharmacological Basis of Therapeutics. California.

Bull E, Marrell J. 2007. Simple Guides Cholesterol. Jakarta: Erlangga.

Cipolle, R.J, Strand, L.M, Morley, P.C. 1998. Pharmaceutical Care Practice. England: McGraw-Hill.

Dewi A.K. 2014. Drug Therapy Problems pada Pasien yang Menerima Resep Polifarmasi. Jakarta: Jurnal Farmasi Komunitas.

Folb P, I. 2012. The Safety of Medicines: Evaluation and Prediction. England: Springer Science and Business Media.

Fradgley S. 2003. Drug Interactions: In Clinical Pharmacy Towards a Rational Treatment and Patient Choice Award. Jakarta: PT Elex Media Komputindo.

Grundy S.M. 2002.Metabolic Syndrome Pandemic: Arteriosclerosis, Thrombosis and Vascular Biology. USA: International Diabetes Federation.

Ito K, Iwatsubo T, Kanamitsu S. 1998. Prediction of Pharmacokinetic Alterations Caused by Drug-drug Interactions: Metabolic Interaction In the Liver. Pharm Rev.

Katzung B.G. 1984. Basic and Clinical Pharmacology $2^{\text {nd }}$ Edition. Lange Med.
Knopp R.H. 1999. Drug Treatment of Lipid Disorders. English: N Engl J Med.

Lestari, Meliyani D, Arifin. 2015. Kajian Interaksi Obat pada Pasien Diabetes Melitus Tipe 2 dengan Hiperlipidemia di RSUD Raden Mattaher. Jambi: Universitas Jambi.

Liman H.H, Hartadi C. 2001. Rabdomiolisis: Efek Samping yang Mungkin Dijumpai Pada Penggunaan Preparat Statin. Jakarta: Departemen Farmakologi UKRIDA.

Nandagopal A, Rao J.V, Kavimani S, Reddy S, Rao E. 2008. Study of Interaction Between Antiobesity and Hyperlipidemic Drugs. Rivers State: Sultan Uloom College of Pharmacy.

Notoatmodjo S.2012. Metodologi Penelitian Kesehatan. Jakarta: RinekaCipta.

Paradina Y.B, Sari D.I, Kartinah N. 2015. Pengaruh Pemberian Simvastatin terhadap Profil Farmakokinetika Rivaroxaban. Banjarmasin: FMIPA Universitas Lambung Mangkurat.

Pelkonen O, Maenpaa J, Taavitsainen P,Rautio A, Raunio H. 1998. Inhibition and Induction of human cytochrome P450 (CYP) enzymes Xenobiotica.

Raich, Chris, Teri D. 1997. Drug Interactions.USA: West Virginia University.

Rakhmaningrum, C. 2013. Studi Terapi Antidislipidemia Pada Pasien 
Hiperlipidemia dengan Komplikasi Stroke Iskemik. Surabaya: Universitas Airlangga.

Riset Kesehatan Dasar [RISKERDAS]. 2007. Laporan Hasil Riset Kesehatan Dasar. Jakarta: Badan Penelitian dan Pengembangan Kesehatan Kementerian Kesehatan RI.

Robinsin S.J, Rubins H.B, Collins D, Fye C.L, Anderson J.W, Elam M.B, Faas F.H. 2015.Veterans Affairs High-Density Lipoprotein Cholesterol Intervention Trial Study Group. English: Engl J Med.

Rosita I, Andrajati R, Zainuddin.2014. Efek Samping Nyeri Otot dari Simvastatin dan Atorvastatin pada Pasien Jantung RSUD Tarakan. Jakarta: Fakultas Farmasi Universitas Indonesia.

Silverman, S. 2000. Oral Cancer Complication of Therapy: Oral Surgery, Oral Medicine, Oral Pathology, Oral Radiology and Endodontics. San Fransisco: University of California.

Siriangkhawut M., Tansakul P., Uchaipichat V. 2016., Prevalence Of Potential Drug Interactions in Thai Patients Receiving Simvastatin: The Causality Assessment of Musculoskeletal Adverse Events Induced by Statin Interaction. Thailand: KhonKaen University.

Stockley I.H, Sweetman S.C. 2008. Stockley's Drug Interactions $8^{\text {th }}$
Edition. London: The Pharmaceutical Press.

Sultanpur C.M, Satyanarayana S. Reddy N.S, Kumar K.E, Kumar S. 2010. Drug-Drug Interaction Between Pravastatin and Gemfibrozil (Antyhiperlipidemic) with Gliclazude (Antidiabetic) in Rats. India: College of Pharmaseutical Science Andhara University.

Tjay T.H, Rahardja, K. 2006. ObatObat Penting: Khasiat, Penggunaan dan Efek Samping Obat. Jakarta: PT Elex Media Komputindo.

Walsky R.L, Obach, R.S. 2004. Validated Assays for Human Cytochrome P450 Activities. Drug Metab Dispos.

Wasis. 2006. Pedoman Riset Praktis Untuk Profesi Perawat. Jakarta: Buku Kedokteran EGC.

Woodward M, Barzi F, Feign V, Gu D, Huxley R, Nakamura K. 2007 Associations Between HDL Cholesterol and Both Stroke and Coronary Heart Disease in the Asia Pacific. Eur Heart J.

Yasin N.M, Widyastuti H.T, Dewi E.K. Kajian Interaksi Obat Pada Pasien Gagal Jantung Kongestif di RSUP Dr. Sardjito Yogyakarta. Yogyakarta: Fakultas Farmasi Universitas Gadjah Mada. 